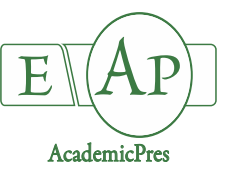

Enescu Mazilu I et al. (2021)

Notulae Botanicae Horti Agrobotanici Cluj-Napoca

Volume 49, Issue 3, Article number 12393

DOI: $10.15835 /$ nbha49312393

Research Article

\title{
Biochemical changes in two Aronia melanocarpa cultivars' berries during the harvest season
}

\author{
Ivona ENESCU MAZILU ${ }^{1,2}$, Mihaela PARASCHIV ${ }^{2}$, \\ Marinela DIACONESCU DINU ${ }^{1}$, Sina N. COSMULESCU ${ }^{3 *}$ \\ ${ }^{1}$ University of Craiova, Doctoral School of Plant and Animal Resources Engineering, Horticulture Faculty, Craiova, 200585, \\ Romania;icmazilu@yahoo.com; marinela_1975@yahoo.com \\ ${ }^{2}$ Research Institute for Fruit Growing Pitesti, 117450, Romania; mihaela1mail@yahoo.ca \\ ${ }^{3}$ University of Craiova, Horticulture Faculty, Department of Horticulture and Food Science, Craiova, 200585, Romania; \\ sinacosmulescu@hotmail.com (*corresponding author)
}

\begin{abstract}
Biochemical changes that undergo during the harvest season in 2020 (between 28 July and 11 September) were evaluated by a comparative study of two Aronia cultivars. The experiment was conducted at the Research Institute for Fruit Growing Pitesti, Arges County, Romania, on 'Melrom' and 'Nero' cultivars. Dry matter, total soluble content, $\mathrm{pH}$, vitamin $\mathrm{C}$, and biologically active components such as anthocyanins and phenolics variations were assessed from 28 July to 11 September 2020, for berries harvested every five days. 'Melrom' cultivar berries had significantly higher dry weight content, $251.43 \mathrm{~g} \mathrm{~kg}^{-1}$. 'Nero' showed a significantly higher vitamin $\mathrm{C}\left(1.87 \mathrm{~g} / \mathrm{kg}^{-1} \mathrm{DW}\right)$, total anthocyanins content $(29.71 \mathrm{~g}$ cyanidin 3 - glucoside $\mathrm{kg}^{-1} \mathrm{DW}$ ), and juice $\mathrm{pH}$ (3.87). As harvest time main effect over the two cultivars taken together, dry weight, anthocyanins, total soluble content, and juice $\mathrm{pH}$ content increased significantly during the harvest season with $43.32 \%, 54.10 \%, 36.33 \%$, and $17.98 \%$, respectively, whereas significant losses of vitamin C, by $26.21 \%$, and total phenolics compounds, by $27.90 \%$, were recorded. Overall, early harvested fruits contained higher levels of moisture, vitamin C, and phenolics compounds, although the last crops provided less acidic fruits, with higher total soluble solids and anthocyanins content.
\end{abstract}

Keywords: antioxidant compounds; black chokeberry; biochemical traits; post maturation

\section{Introduction}

Aronia melanocarpa (Michx.) Elliot, native to eastern North America, was brought to Europe at the end of the 19th century and draw attention by its fruits with high content of biologically active compounds that justifies the wide range of therapeutic benefits. It is estimated that $A$. melanocarpa fruits have a high concentration of phenolics, predominated by condensed tannins, up to $66 \%$ of total phenolics (Oszmiański and Wojdylo, 2005), which are responsible for the astringent sensation when tasting, but especially for the remarkable biological activity of fruits or fruit extracts. The level of nutritive and non - nutritive components in chokeberry differs between cultivars (Ochmian et al., 2012; Wangensteen et al., 2014), from one location to another (Won et al., 2018), depending on soil type (Djuric et al., 2015), climatic factors (Sim et al., 2017; Tolić 
et al., 2017), fruit ripening stage (Jeppsson and Johansson, 2000; Yang et al., 2019), and is also influenced by the agrotechnical approach (Remberg et al., 2014). In Romania, Aronia melanocarpa berries ripen in AugustSeptember, i.e. 80 - 90 days after the end of the flowering period. Chokeberries have a less common feature, namely long persistence on the branches after ripen (even in winter), eventually dehydrating if not harvested, being challenging to establish an optimum picking moment. Moreover, berries colour unchanged (when visual observed) after the ripening process stops, so the epicarp colour cannot be used as an instrument influencing the harvest decision. Unharvested berries accumulate sugars and lose acidity, perfecting their taste, while different biologically active component dynamics have been reported. The present paper aims to quantify a series of biochemical traits in chokeberries post - ripening period, to guide the harvest decision, for two Aronia cultivars, 'Melrom', and 'Nero' in Arges County, Romania.

\section{Materials and Methods}

The study was carried out at Research Institute for Fruit Growing Pitești Argeș County (445ㄴ' $\mathrm{N}$, 24'52'E), Romania in 2020. Aronia melanocarpa plant material consisted of 3 years 'Melrom' cultivar, respectively in 7 years 'Nero' cultivar, planted at $3.5 \mathrm{~m}$ inter-row spacing and $1.4 \mathrm{~m}$ in row distance. The experimental plots were not provided with an irrigation system. A bifactorial experiment, with 5 randomized plants, in three replications for each cultivar was established. The first experimental factor, Aronia melanocarpa cultivar, had two levels, 'Melrom' (obtained by free breeding at Research Institute for Fruit Growing Pitesti) and 'Nero' (Chech Republic). The second experimental factor was represented by the harvest time (HT), with 10 levels (the first harvest performed on 28 July 2020, the second harvest on 2 August 2020, and so, with 11 September 2020 as the last harvest moment). The first berries were cropped when fully ripened (28 July 2020). The process was repeated every five days until about $25 \%$ of fruits became dehydrated (after 11 September 2020). The collected fruits were divided into three replication and kept at $-18{ }^{\circ} \mathrm{C}$ until the laboratory analysis (November 2020). Total soluble solids (TSS) and pH were measured with a Kern digital refractometer (with Brix grades units) and mini-Lab pH-meter. The gravimetrical method was used for dry weight (DW) content assessment, by drying $10 \mathrm{~g}$ fresh fruits in an oven at $105^{\circ} \mathrm{C}$ until a constant mass was reached. Vitamin $\mathrm{C}$ (Vit. C) content was estimated with the iodometric method (Sapožnikova and Dorofiejeva, 1966) and expressed as $\mathrm{g} \mathrm{kg}^{-1} \mathrm{DW}$. For total phenolics content (TPC), the spectrophotocolorimetric method was used, with Folin Ciocâlteu reagent (Cosmulescu et al., 2017), methanol (70\%) as extraction solvent, and the results were expressed as g gallic acid equivalents (GAE) per kg DW. Fuleki and Francis (1968) method was used for total anthocyanin content (TAC) determination (expressed as cyanidin 3 - glucoside (cy 3 - glu) $\mathrm{kg}^{-1} \mathrm{DW}$ ). Statistical analysis was performed with a free trial of IBM SPSS Statistics 20 software. Two-way ANOVA and Duncan Multiple Range Tests at $\mathrm{p}<0.05$ were used. Three independent samples were considered for each harvest moment per cultivar and the resulting data were used to obtain average values and standard deviations for all tests. Microsoft Excel was chosen for data graphic representation.

\section{Results and Discussion}

Evaluation of Aronia berries during the harvest season performed in this study showed that the harvest time (HT) and cultivar $x \mathrm{HT}$ interaction significantly influenced all determined parameters. At the same time, a weaker response induced the cultivar, with no significant effect over TPC and TSS (Table 1).

Table 2 presents measures of the central tendency (mean and median) and measures of the variability (standard deviation, variation coefficient, the minimum, and maximum absolute variables) of data set regarding DW, vitamin C, TPC, TAC, TSS, and juice $\mathrm{pH}$ determined in 'Melrom' and 'Nero' cultivars taken together $(\mathrm{n}=6)$ and separately $(\mathrm{n}=3)$. 
Table 1. Cultivar and harvest time (HT) main effects, and cultivar x HT interaction effect significance over dry weight (DW), vitamin C, total phenolic (TP), total anthocyanin content (TAC), total soluble solids (TSS) content, and juice $\mathrm{pH}$ on Aronia melanocarpa 'Melrom' and 'Nero' cultivars

\begin{tabular}{|c|c|c|c|c|c|c|c|}
\hline \multirow{4}{*}{ 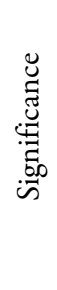 } & Experimental factor & DW content & Vitamin C & TPC & TAC & TSS content & Juice $\mathrm{pH}$ \\
\hline & Cultivar & $\begin{array}{c}* * \\
(\mathrm{p}=0.010)\end{array}$ & $\begin{array}{c}* * * \\
(\mathrm{p}=0.000)\end{array}$ & $\begin{array}{c}\text { n.s. } \\
(p=0.114)\end{array}$ & $\begin{array}{c}* * * \\
(\mathrm{p}=0.000)\end{array}$ & $\begin{array}{c}\text { n.s. } \\
(p=0.221)\end{array}$ & $\begin{array}{c}* * \\
(p=0.002)\end{array}$ \\
\hline & Harvest time (HT) & $(\mathrm{p}=0.000)$ & $(\mathrm{p}=0.000)$ & $\begin{array}{c}* * * \\
(p=0.000)\end{array}$ & $(\mathrm{p}=0.000)$ & $(p=0.000)$ & $\begin{array}{c}* * * \\
(\mathrm{p}=0.000)\end{array}$ \\
\hline & $\begin{array}{c}\text { Cultivar } \\
\text { x HT }\end{array}$ & $\begin{array}{c}* * * \\
(p=0.000)\end{array}$ & $\begin{array}{c}* * * \\
(\mathrm{p}=0.000)\end{array}$ & $\begin{array}{c}* \\
(p=0.023)\end{array}$ & $\begin{array}{c}* * * \\
(p=0.000)\end{array}$ & $\begin{array}{c}* * * \\
(p=0.001)\end{array}$ & $\begin{array}{c}* \\
(p=0.033)\end{array}$ \\
\hline
\end{tabular}

Significance letters and symbols refer to cultivar, harvest time (HT) and cultivar $\mathrm{x}$ HT interaction efects: n.s. = nonsignificant; ${ }^{*}=$ significant $($ at $\mathrm{p} \leq 0.05),{ }^{* *}=$ highly significant $($ at $\mathrm{p} \leq 0.01)$, and ${ }^{* * *}=$ very significant $($ at $\mathrm{p} \leq 0.001$, respectively.

Table 2. Statistical descriptors (mean, median, standard deviation, variation coefficient, minimum absolute, and maximum absolute) for DW, vitamin C, TPC, TAC, TSS, and juice $\mathrm{pH}$ on $A$. melanocarpa (Michx.) Elliot, 'Melrom' and 'Nero' cultivars

\begin{tabular}{|c|c|c|c|c|c|c|c|}
\hline Cultivar & $\begin{array}{l}\text { Statistical } \\
\text { descriptors }\end{array}$ & $\begin{array}{c}\text { DW } \\
\left(\mathrm{g} \mathrm{kg}^{-1}\right)\end{array}$ & $\begin{array}{c}\text { Vitamin C } \\
\left(\mathrm{g} \mathrm{kg}^{-1}\right. \\
\mathrm{DW})\end{array}$ & $\begin{array}{c}\text { TPC } \\
\text { (g GAE kg-1 } \\
\text { DW) }\end{array}$ & $\begin{array}{l}\text { TAC (g cy 3- } \\
\text { glu kg-1 DW) }\end{array}$ & TSS $\left({ }^{\circ}\right.$ Brix $)$ & $\begin{array}{c}\text { Juice } \\
\mathrm{pH}\end{array}$ \\
\hline \multirow{6}{*}{$\begin{array}{l}\text { 'Melrom' } \\
\text { and 'Nero', }\end{array}$} & Mean & 248.4 & 1.74 & 67.26 & 23.34 & 19.54 & 3.82 \\
\hline & Median & 254.9 & 1.73 & 67.02 & 20.5 & 20 & 3.75 \\
\hline & Std. deviation & 27.39 & 0.27 & 6.55 & 7.57 & 2.35 & 0.24 \\
\hline & Var. coeff. & 11.03 & 15.52 & 9.74 & 32.43 & 12.03 & 6.28 \\
\hline & $\begin{array}{l}\text { Minimum } \\
\text { absolute }\end{array}$ & 188.90 & 1.31 & 48.42 & 14.09 & 13.40 & 3.42 \\
\hline & $\begin{array}{l}\text { Maximum } \\
\text { absolute }\end{array}$ & 293.80 & 2.24 & 81.35 & 36.80 & 23.40 & 4.40 \\
\hline \multirow{6}{*}{ 'Melrom' } & Mean & 251.43 & 1.6 & 66.53 & 16.98 & 19.37 & 3.77 \\
\hline & Median & 256.2 & 1.54 & 67.12 & 16.3 & 19.85 & 3.75 \\
\hline & Std. deviation & 21.74 & 0.22 & 5.97 & 1.98 & 1.69 & 0.19 \\
\hline & Var. coeff. & 8.65 & 13.75 & 8.97 & 11.66 & 8.72 & 5.04 \\
\hline & $\begin{array}{l}\text { Minimum } \\
\text { absolute }\end{array}$ & 193.50 & 1.32 & 48.42 & 14.09 & 15.90 & 3.48 \\
\hline & $\begin{array}{l}\text { Maximum } \\
\text { absolute }\end{array}$ & 276.20 & 2.11 & 74.23 & 20.76 & 21.60 & 4.30 \\
\hline \multirow{6}{*}{ 'Nero' } & Mean & 245.36 & 1.87 & 67.99 & 29.71 & 19.71 & 3.87 \\
\hline & Median & 248.15 & 1.92 & 67.02 & 31.09 & 20.65 & 3.75 \\
\hline & Std. deviation & 32.16 & 0.25 & 7.11 & 5.36 & 2.89 & 0.29 \\
\hline & Var. coeff. & 13.11 & 13.37 & 10.46 & 18.04 & 14.66 & 7.49 \\
\hline & $\begin{array}{l}\text { Minimum } \\
\text { absolute }\end{array}$ & 188.90 & 1.31 & 53.63 & 20.12 & 13.40 & 3.42 \\
\hline & $\begin{array}{l}\text { Maximum } \\
\text { absolute }\end{array}$ & 293.80 & 2.24 & 81.35 & 36.80 & 23.40 & 4.40 \\
\hline
\end{tabular}

For both cultivars taken together, on average, Aronia berries had $248.40 \pm 27.39 \mathrm{~g} \mathrm{~kg}^{-1} \mathrm{DW}$ (spread between 188.90 and $\left.293.80 \mathrm{~g} \mathrm{~kg}^{-1}\right), 1.74 \pm 0.27 \mathrm{~g} \mathrm{~kg}^{-1} \mathrm{DW}$ Vit. C (with a minimum of 1.32 and a maximum of $2.24 \mathrm{~g} \mathrm{~kg}^{-1} \mathrm{DW}$ ), $67.26 \pm 6.55 \mathrm{~g} \mathrm{GAE} \mathrm{kg}^{-1} \mathrm{DW}$ TPC (that ranged from 48.42 to $81.35 \mathrm{~g} \mathrm{GAE} \mathrm{kg}^{-1} \mathrm{DW}$ ), 23.34 $\pm 7.57 \mathrm{~g} \mathrm{cy} 3-$ glu kg$^{-1} \mathrm{DW}$ TAC (that varied between $14.09-36.80 \mathrm{gcy} 3-\mathrm{glu} \mathrm{kg}^{-1} \mathrm{DW}$ ). The average TSS counted $19.54 \pm 2.35^{\circ} \mathrm{Brix}$ (with $13.4-23.4^{\circ} \mathrm{Brix}$ ) and $3.82 \pm 0.24$, for juice $\mathrm{pH}(3.42-4.40)$. Examining the 
variation coefficient data revealed that the Aronia TAC showed high variability (32.43\%), while juice $\mathrm{pH}$ had the lowest one (6.28\%). For all other parameters, medium values of variation coefficients were recorded (from 9.74 to $15.52 \%$ ). Also, comparing the two cultivars resulted in higher variability for all quality parameters in 'Nero', except vitamin C (for vitamin C 'Melrom' and 'Nero' had similar variation coefficients).

\section{Dry weight content}

The dry matter content varies during the different stages of fruit development, and its dynamics make DW an appropriate indicator of maturity for both climacteric and non-climacteric fruits. The accumulation of DW is related not only to the cultivar (or genotype) but also to the crop technology and field factors. The degree of ripeness of the fruit at harvest is reflected in the taste of the fruit and is a strong determinant of the success of the crop market.

During the harvest season, Aronia melanocarpa 'Melrom' cv. berries mean dry weight content was higher $(\mathrm{p}=0.010), 251.43 \mathrm{~g} \mathrm{~kg}^{-1}$ (Figure 1), compared with 'Nero' $\left(245.36 \mathrm{~g} \mathrm{~kg}^{-1}\right)$. Nevertheless, the cultivar effect size was small (partial eta squared 0.156), in contrast to the harvest time and cultivar $\times$ harvest time interaction effect (partial eta squared 0.921 and 0.659 , respectively).

DW content started to increase significantly on 2 August, in 'Melrom', and five days later in 'Nero'. Overall, delaying the harvest moment increased DW content by $43.32 \%$, from 196.97 on 28 July to $282.30 \mathrm{~g}$ $\mathrm{kg}^{-1}$ on 11 September as Figure 2 presents. The cultivar $\times \mathrm{HT}$ interaction resulted in $40.82 \%$, for 'Melrom' and $45.78 \%$, for 'Nero' significantly higher DW content at the end of the harvest season. Also, there was observed a higher DW for 'Nero' (290.43 $\left.\mathrm{g} \mathrm{kg}^{-1}\right)$ compared with 'Melrom' (274.17 $\left.\mathrm{g} \mathrm{kg}^{-1}\right)$ on the last harvested berries, although on 2 August 'Nero' reached the cultivar's lowest DW content, $196.27 \mathrm{~g} \mathrm{~kg}^{-1}$.

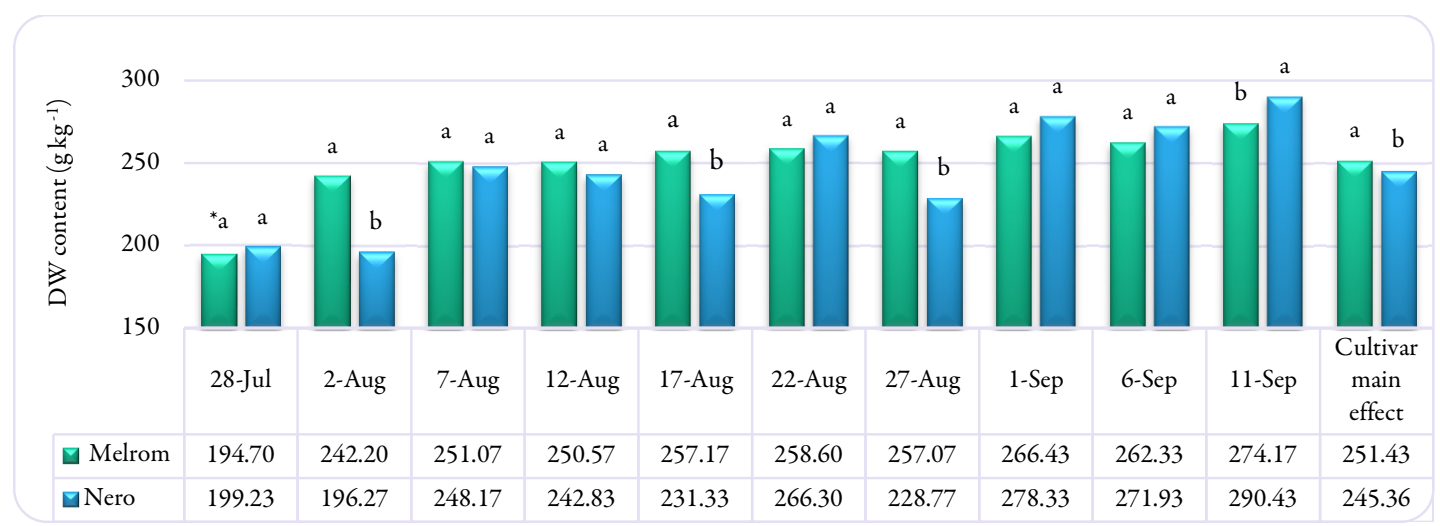

Figure 1. Cultivar effect depending on HT and cultivar main effect on DW content on $A$. melanocarpa (Michx.) Elliot, 'Melrom' and 'Nero' cultivars (each value represents the average of three determination results)

${ }^{*}$ Different letters within the columns indicate statistically significant differences (Duncan's multiple range test, $\mathrm{p}<0.05$ )

Antioxidant components as vitamin $\mathrm{C}$, polyphenols, and anthocyanins of fruits and vegetables are influenced by factors as genotype, cultural practice, climatic conditions, maturity grade, and postharvest management. Based on their dietary importance and chemical instability (under temperature, oxygen, light, and $\mathrm{pH}$ influence), the antioxidants are markers of the fruit quality and fruit's functional food value. 


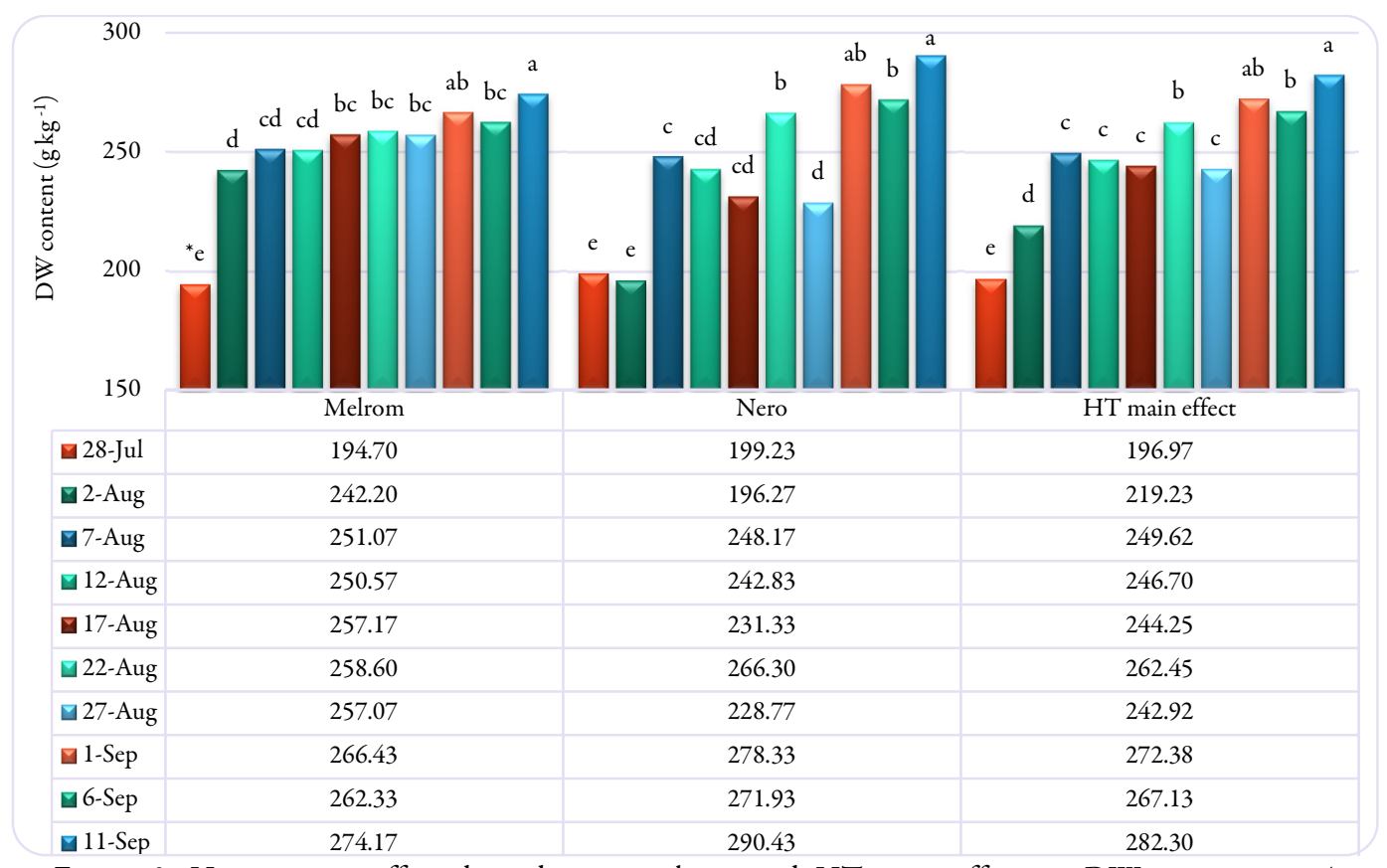

Figure 2. Harvest time effect depending on cultivar and HT main effect on DW content on $A$. melanocarpa (Michx.) Elliot, 'Melrom' and 'Nero' cultivars (each value represents the average of three determination results)

*Different letters within the columns indicate statistically significant differences (Duncan's multiple range test, $\mathrm{p}<0.05$ )

\section{Vitamin C content}

According to Hornung and Biesalski (2019), during evolution, some species including humans, monkeys, and bats lost the ability for ascorbic acid (AA) biosynthesis due to the inactivation of the enzyme Lgluconolactone oxidase (GLO) and subsequently became dependent on dietary vitamin C. Fresh fruits and vegetables are the major sources of vitamin $\mathrm{C}$. In the human organism, vitamin $\mathrm{C}$ main role is antioxidant and cofactor in redox reactions but recently was reported its implication in the activation of epigenetic mechanisms controlling cell differentiation, dysregulation of which can lead to the development of certain types of cancer.

In A. melanocarpa, for the 28 July - 11 September harvest interval, higher mean vitamin $\mathrm{C}$ content ( $\mathrm{p}=0.000$ ) was found in 'Nero' ( 1.87 , versus $1.60 \mathrm{~g} \mathrm{~kg}^{-1} \mathrm{DW}$, in 'Melrom'), as Figure 3 presents. The cultivar effect size was high (partial eta squared 0.770) and confirmed that there was an important difference between cultivars. A similar effect size was obtained for harvest time and $\mathrm{cv} . \times$ harvest time interaction (partial eta squared 0.876 and 0.679). Until the last harvest moment (11 September 2020), Aronia berries lost $26.21 \%$ of their vitamin C content registered on $28 \mathrm{July}$ (from 2.06 to $1.52 \mathrm{~g} \mathrm{~kg}^{-1} \mathrm{DW}$ ) (Figure 4). The two experimental factors interaction effect appeared in 23.56\% for 'Melrom' and 28.92\% for 'Nero' vitamin C loss. Moreover, a higher, although non-significant, vitamin C content, on 'Melrom' (compared to 'Nero') was recorded for the first and last harvested berries. On all other harvest moments, 'Nero' vitamin C content exceeded 'Melrom' and the difference between cultivars was accentuated on 12 August 2020. Also, the significant loss of vitamin C started on 2 August, for 'Melrom' while for 'Nero' the significant vitamin C decrease started 20 days later, on 22 August (Figure 4). 


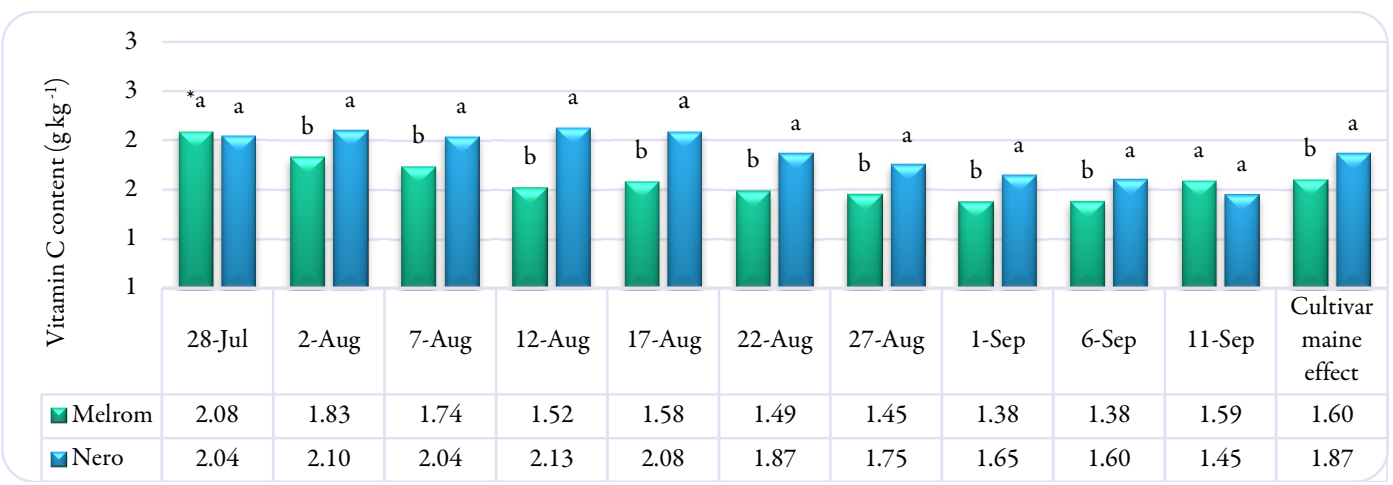

Figure 3. Cultivar effect depending on HT and cultivar main effect on vitamin C content on $A$. melanocarpa (Michx.) Elliot, 'Melrom' and 'Nero' cultivars (each value represents the average of three determination results)

${ }^{*}$ Different letters within the columns indicate statistically significant differences (Duncan's multiple range test, $\mathrm{p}<0.05$ )

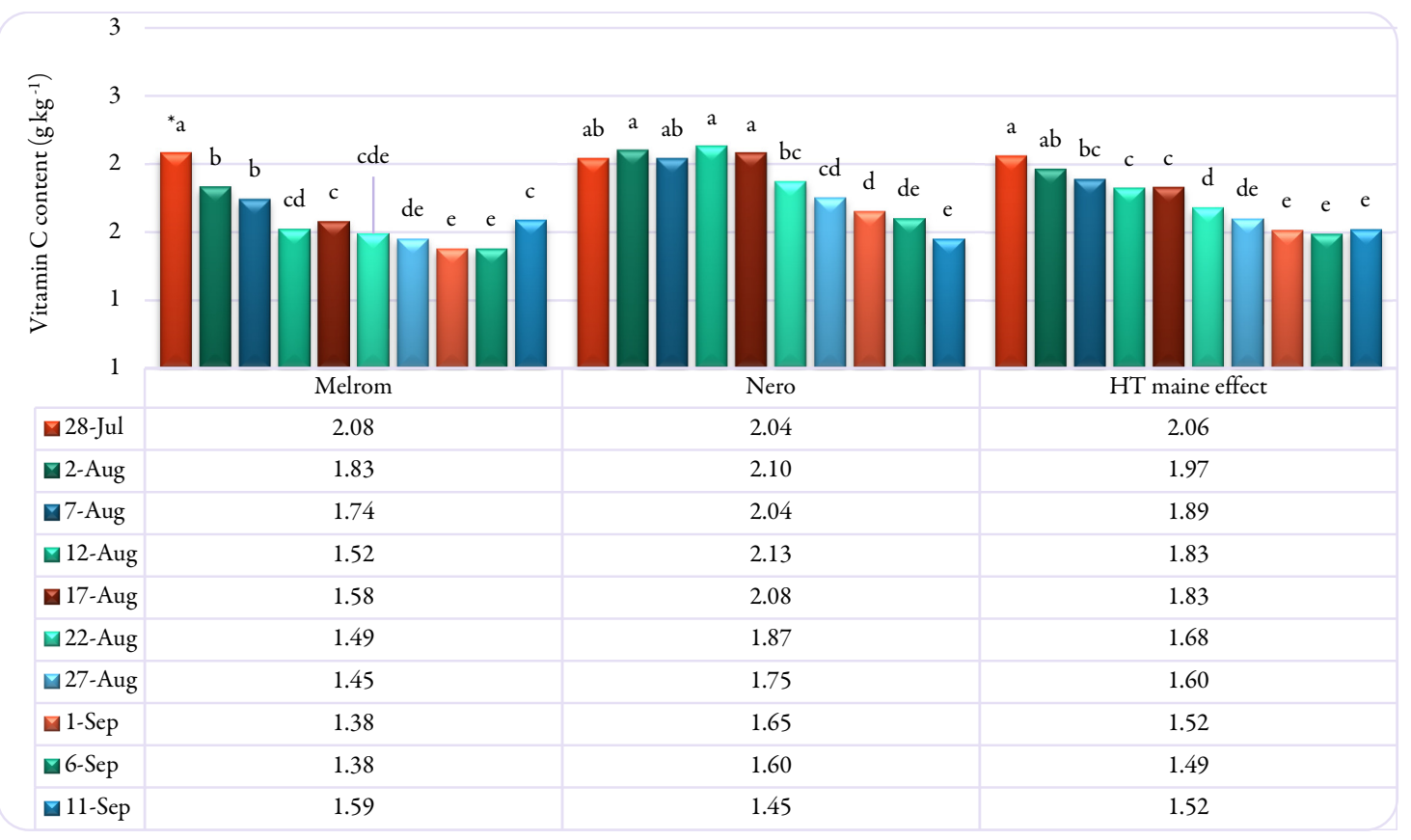

Figure 4. Harvest time effect depending on cultivar and HT main effect on vitamin $\mathrm{C}$ content on $A$. melanocarpa (Michx.) Elliot, 'Melrom' and 'Nero' cultivars (each value represents the average of three determination results)

*Different letters within the columns indicate statistically significant differences (Duncan's multiple range test, $\mathrm{p}<0.05$ )

\section{Total phenolics content}

With no significant cultivar influence $(\mathrm{p}=0.114)$, as presented in Figure 5, total phenolics content decreased on the latest harvested berries by $27.90 \%$, between 75.83 and $54.67 \mathrm{~g} \mathrm{GAE} \mathrm{kg}^{-1} \mathrm{DW}$ (Figure 6). The harvest time showed a very significant influence on TPC and also had a high effect size (partial eta squared 0.779), which means that it could be an important factor to consider when picking chokeberry. The cultivar $x$ HT interaction manifested in $27.24 \%$ and $28.51 \%$ for 'Melrom' and 'Nero', respectively TPC loss on 11 September over 28 July. 'Nero' showed significantly higher TPC than 'Melrom' for the first harvested berries (79.68 compared with $71.98 \mathrm{~g} \mathrm{GAE} \mathrm{kg}^{-1} \mathrm{DW}$ ), while no other significant differences until the end of the harvest 
season were recorded. Moreover, the first significant TPC decrease was observed on 7 August, for 'Nero' whereas for 'Melrom', TPC significantly decreased 20 days later (Figure 6). Unlike our results, for 'Viking' Aronia cultivar, Bolling et al. (2015) reported a $24 \%$ increase in juice phenolic content (from 4.03 to $5.03 \mathrm{mg}$ $\mathrm{GAE} \mathrm{ml}^{-1}$ ) at the end of a 7 - week harvest experiment.

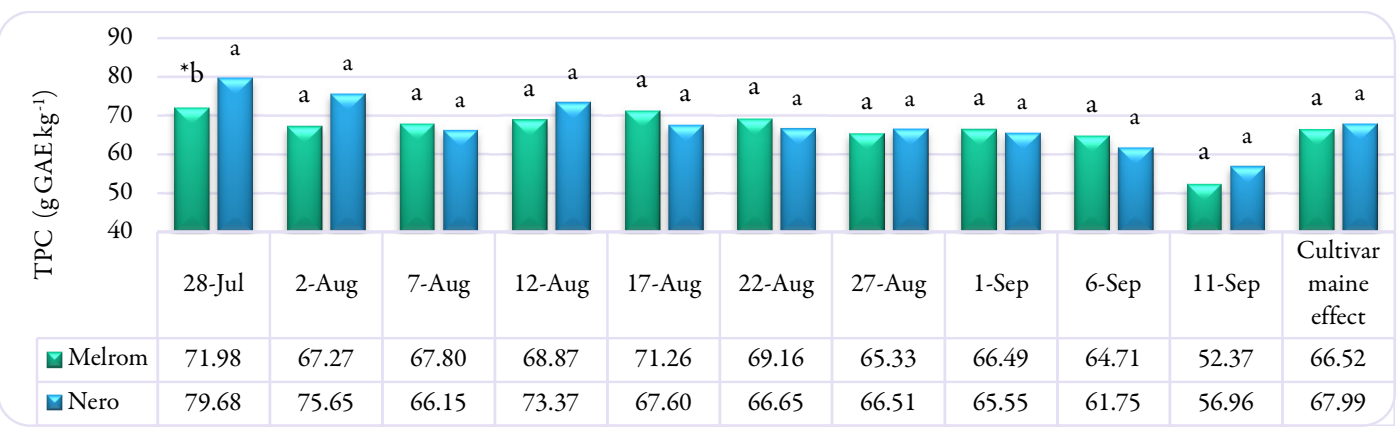

Figure 5. Cultivar effect depending on HT and cultivar main effect on total phenolics content on $A$. melanocarpa (Michx.) Elliot, 'Melrom' and 'Nero' cultivars (each value represents the average of three determination results)

${ }^{*}$ Different letters within the columns indicate statistically significant differences (Duncan's multiple range test, $\mathrm{p}<0.05$ )

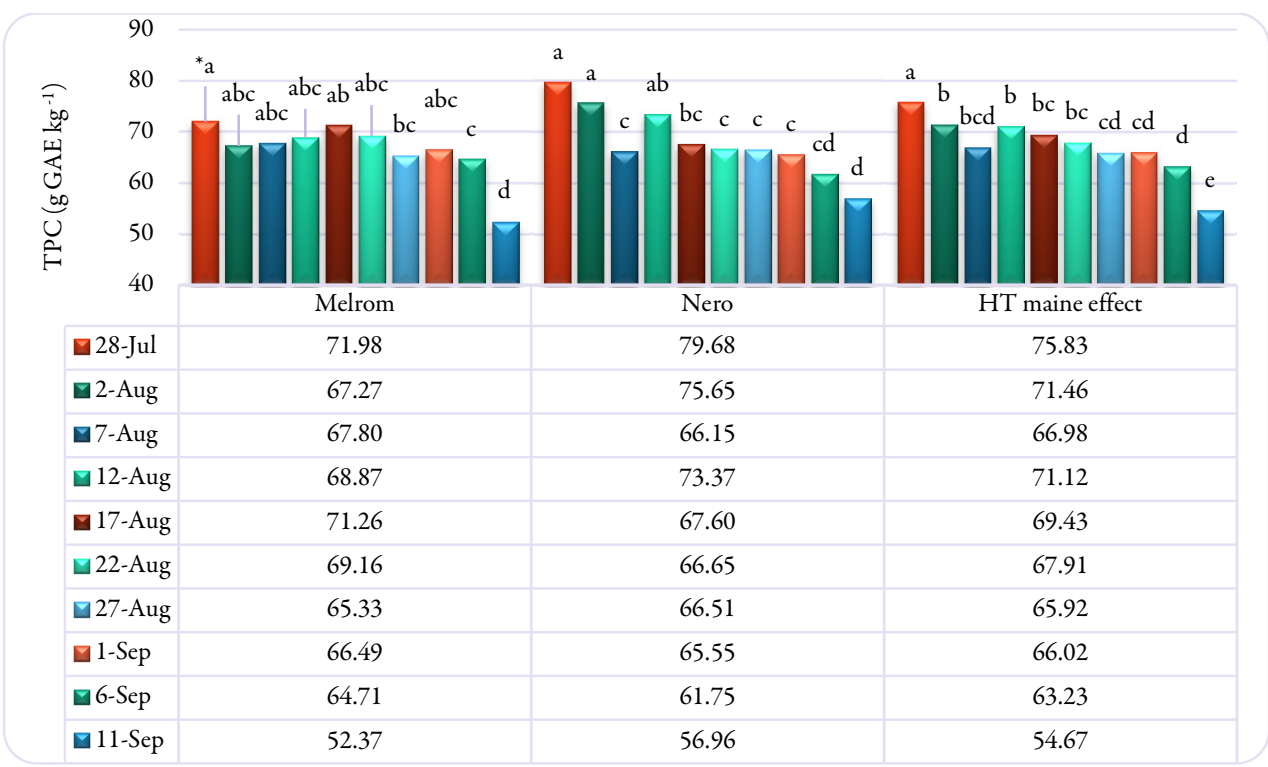

Figure 6. Harvest time effect depending on cultivar and HT main effect on total phenolics content on $A$. melanocarpa (Michx.) Elliot. 'Melrom' and 'Nero' cultivars (each value represents the average of three determination results)

${ }^{*}$ Different letters within the columns indicate statistically significant differences (Duncan's multiple range test, $\mathrm{p}<0.05$ )

\section{Total anthocyanins content}

TAC determined for 'Nero' cv. was higher $(\mathrm{p}=0.000)$ when compared with 'Melrom' (29.71 g cy 3-glu $\mathrm{kg}^{-1} \mathrm{DW}$ versus 16.98) as presented in Figure 7. All three experimental factors had a large effect size on the total anthocyanin content (partial eta squared $0.985,0.944$, and 0.881 ). It can be stated, therefore, that TAC responded more strongly to the effect of experimental factors than any other quality indicator. During the harvest season, TAC content varied significantly, following an upward trend (Figure 8), with a gain of $54.10 \%$ until 11 September (from $17.67 \mathrm{~g}$ cy 3 -glu kg ${ }^{-1} \mathrm{DW}$ to 27.23). The experimental factors interaction resulted in 
40.83\% ('Melrom') and 63.60\% ('Nero') anthocyanins increase from the first to the last harvest day. It was highlighted a stronger effect of cultivar on 12 August, raising the difference (significant otherwise during the entire harvest season) between the two cultivars. Unlike 'Melrom', in 'Nero', TAC increased significantly five days later (on 7 August), but reached their maximum 15 days earlier, on 27 August (Figure 8).

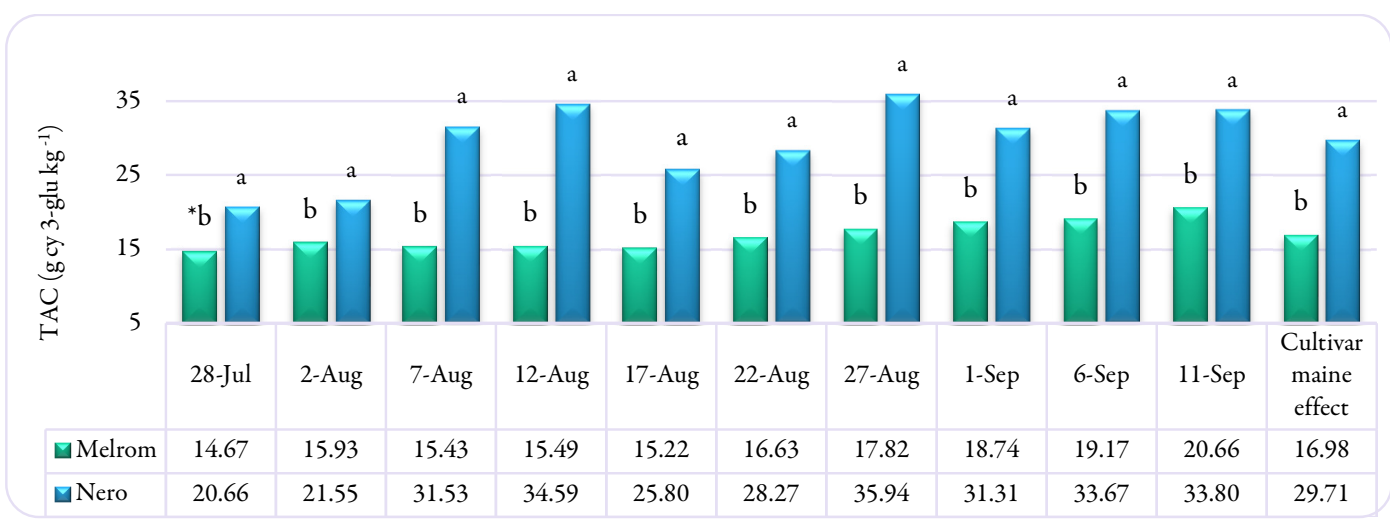

Figure 7. Cultivar effect depending on HT and cultivar main effect on total anthocyanins content on A. melanocarpa (Michx.) Elliot, 'Melrom' and 'Nero' cultivars (each value represents the average of three determination results)

${ }^{*}$ Different letters within the columns indicate statistically significant differences (Duncan's multiple range test, $\mathrm{p}<0.05$ )

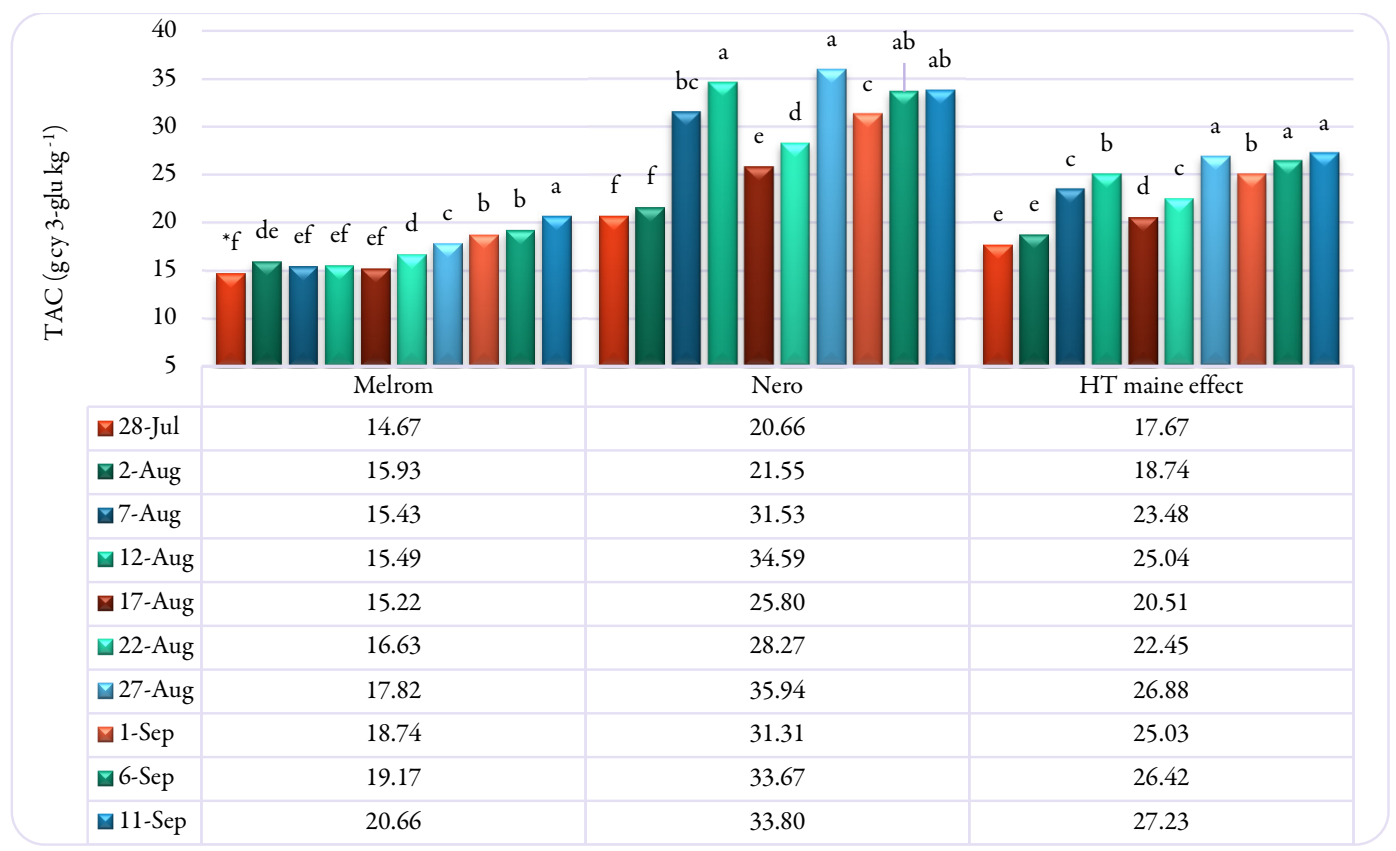

Figure 8. Harvest time effect depending on cultivar and HT main effect on total anthocyanins content on A. melanocarpa (Michx.) Elliot, 'Melrom' and 'Nero' cultivars (each value represents the average of three determination results)

*Different letters within the columns indicate statistically significant differences (Duncan's multiple range test, $\mathrm{p}<0.05$ )

A similar tendency of anthocyanins increasing, that coincided with phenolics decreasing was remarked by Gralec et al. (2019). Also, in Bolling et al. (2015) study was reported that 'Viking' chokeberry juice anthocyanins doubled at the fifth harvest week and decreased after that. Bolling et al. (2015) found that the 
initial total anthocyanin content of Aronia juice was $366 \pm 3 \mu \mathrm{g}$ per $\mathrm{mL}$ and peaked at $1200 \mu \mathrm{g}$ per $\mathrm{mL}$ at the 5th week, and then decreased to $817 \mu \mathrm{g}$ per $\mathrm{mL}$ at the final harvest (7th week).

\section{Total soluble solids}

Total soluble solids (TSS) content varied non - significantly $(\mathrm{p}=0.221)$ under cultivar influence (Figure 9), but increased very significantly by $36.33 \%$ until the last harvest moment, showing a strong harvest time effect size and medium effect size for cultivar $\times$ harvest time interaction (partial eta square 0.937 and 0.490 , respectively). Following the same trend as DW, TSS started to increase on 2 August, for 'Melrom', and five days later for 'Nero'. The influence of cultivar $\times$ harvest moment interaction resulted in $21.86 \%$, for 'Melrom' and $52.19 \%$ for 'Nero', higher values on 11 September compared with 28 July (Figure 10). There was observed that 'Melrom' reached higher TSS than Nero on 2 August and 'Nero' berries' TSS exceeded 'Melrom' on 12 August and 11 September, with no other significant differences. 'Melrom' hits its maximum TSS $\left(21.17^{\circ} \mathrm{Brix}\right)$ 10 days earlier than 'Nero' (22.57 on 11 September) (Figure 10). In similar studies, TSS content of Aronia juice increased from 10.5 to $14.33^{\circ}$ Brix between the first and the 7 th harvest week, representing a $36 \%$ increase over the harvest period, as Bolling et al. (2015) found. Aronia cultivars studied in the present experiment had higher TSS content $\left(13.4-23.4^{\circ} \mathrm{Brix}\right)$ comparing with 'Viking' $\left(7.8-14.3^{\circ} \mathrm{Brix}\right)$ as reported by Bolling et al. (2015). Similar TSS values, $13-19^{\circ}$ Brix, were obtained in Strik et al. (2003) research. Also, Šnebergrová et al. (2014) found a TSS of $19.9^{\circ}$ Brix in Aronia melanocarpa, 'Nero' cultivar in the Czech Republic.

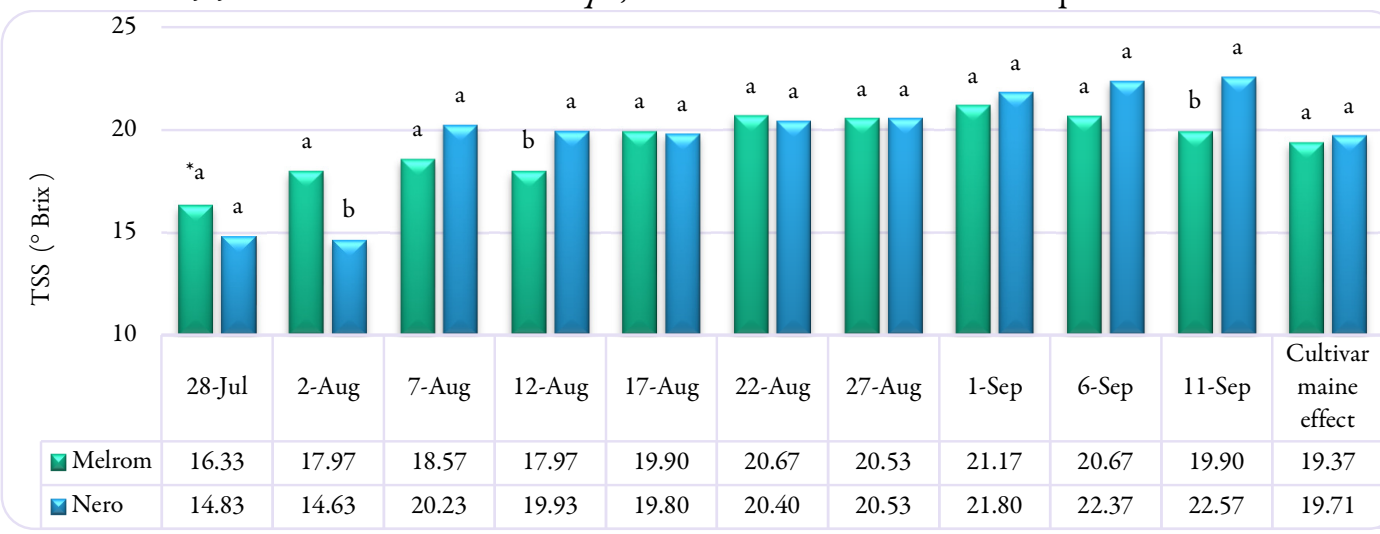

Figure 9. Cultivar effect depending on HT and cultivar main effect on total soluble solids content on $A$. melanocarpa (Michx.) Elliot, 'Melrom' and 'Nero' cultivars (each value represents the average of three determination results)

*Different letters within the columns indicate statistically significant differences (Duncan's multiple range test, $\mathrm{p}<0.05$ ) 


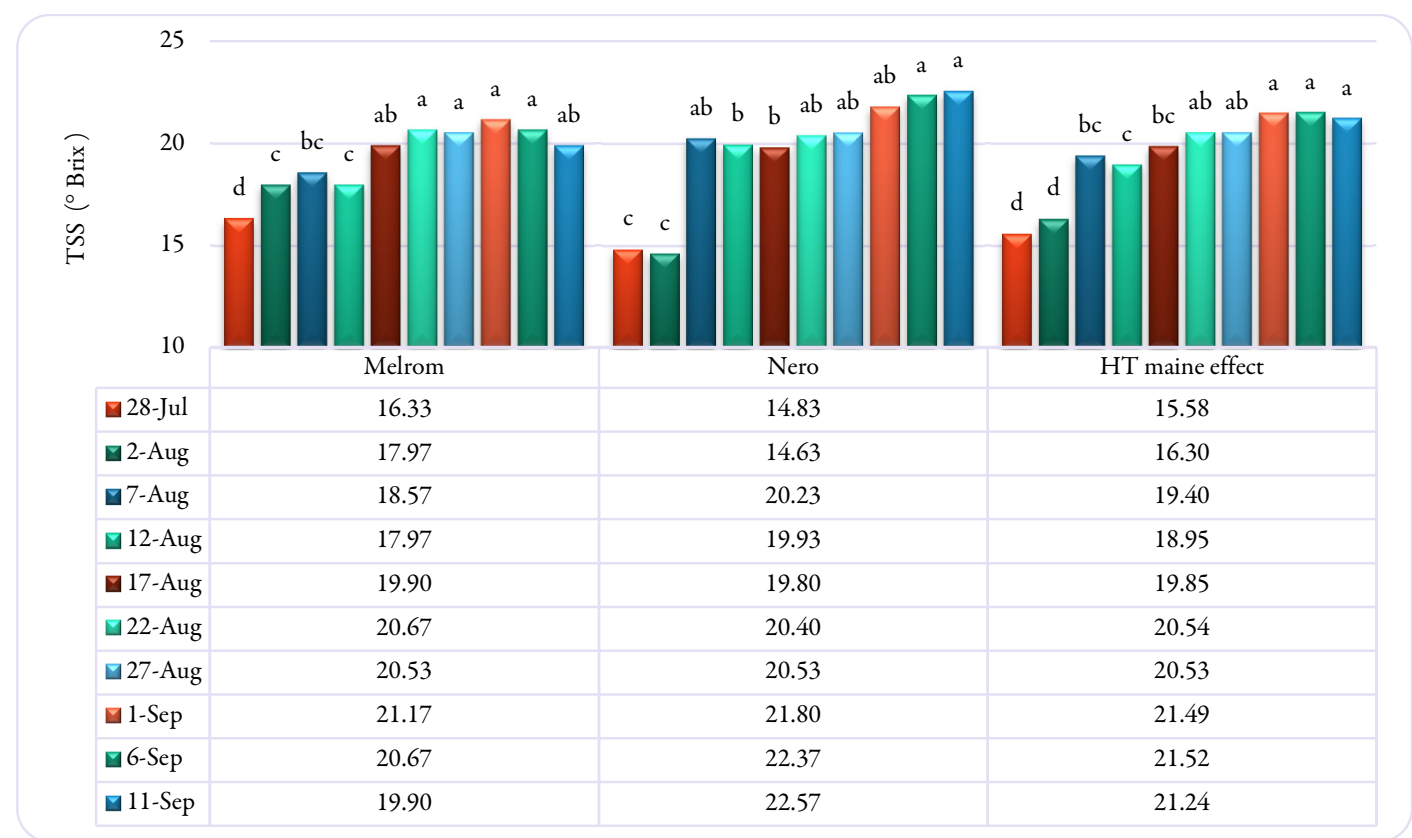

Figure 10. Harvest time effect depending on cultivar and HT main effect on total soluble solids on $A$. melanocarpa (Michx.) Elliot, 'Melrom' and 'Nero' cultivars (each value represents the average of three determination results)

${ }^{*}$ Different letters within the columns indicate statistically significant differences (Duncan's multiple range test, $\mathrm{p}<0.05$ )

\section{Juice $p H$}

Regarding juice $\mathrm{pH}$, the less acidic fruits $(\mathrm{p}=0.002)$ belonged to 'Nero' cultivar $(\mathrm{pH} 3.87$ versus 3.77 , for 'Melrom'), as Figure 11 illustrate. Regarding the experimental factors effect size, cultivar and cultivar harvest time were weak, while a strong effect had the harvest time (partial eta square $0.225,0.343$, and 0.825, respectively). Our results were similar to those obtained in Tolić et al. (2017) research during the 2012-2014 growing seasons $(3.96,3.77$, and 3.94). Until the final harvest moment juice $\mathrm{pH}$ increased by $17.98 \%$ (Figure 12). The experimental factors interaction materialized in $14.29 \%$ ('Melrom') and $21.69 \%$ ('Nero') increase during the harvested season and on significantly higher $\mathrm{pH}$ values of 'Nero' fruit juice on the last picking moment. The $\mathrm{pH}$ value increased significantly on 17 August, for 'Nero' and 1 September for 'Melrom'. A similar $\mathrm{pH}$ profile was reported by Bolling et al. (2015): an acidity decrease from the 4th to the 7th week. although they observed no significant difference between the 7 th harvest weeks.

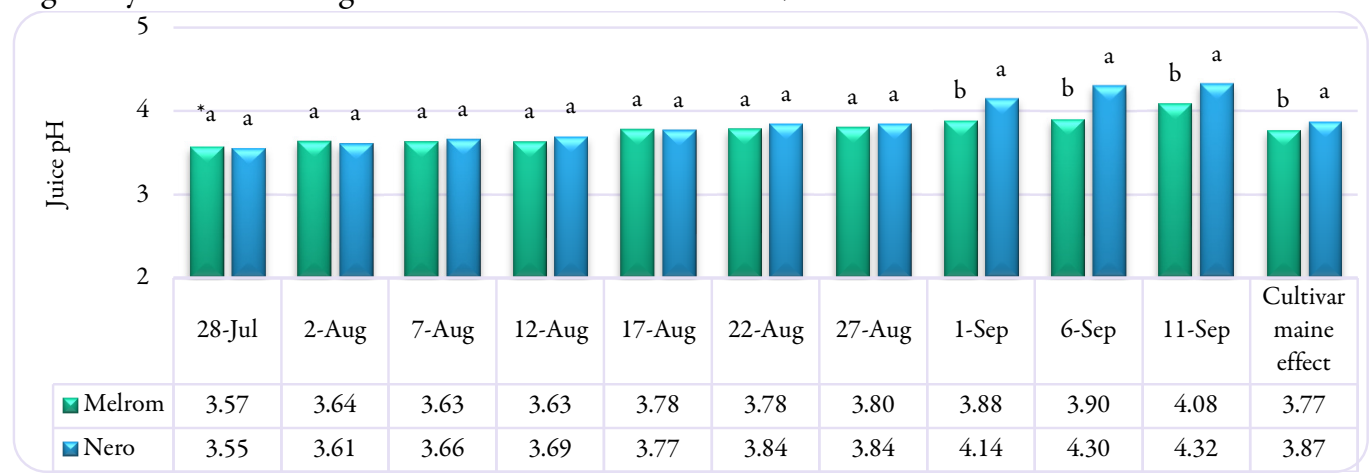

Figure 11. Cultivar effect depending on HT and cultivar main effect on juice $\mathrm{pH}$ on $A$. melanocarpa (Michx.) Elliot, 'Melrom' and 'Nero' cultivar (each value represents the average of three determination results)

${ }^{*}$ Different letters within the columns indicate statistically significant differences (Duncan's multiple range test, $\mathrm{p}<0.05$ ) 


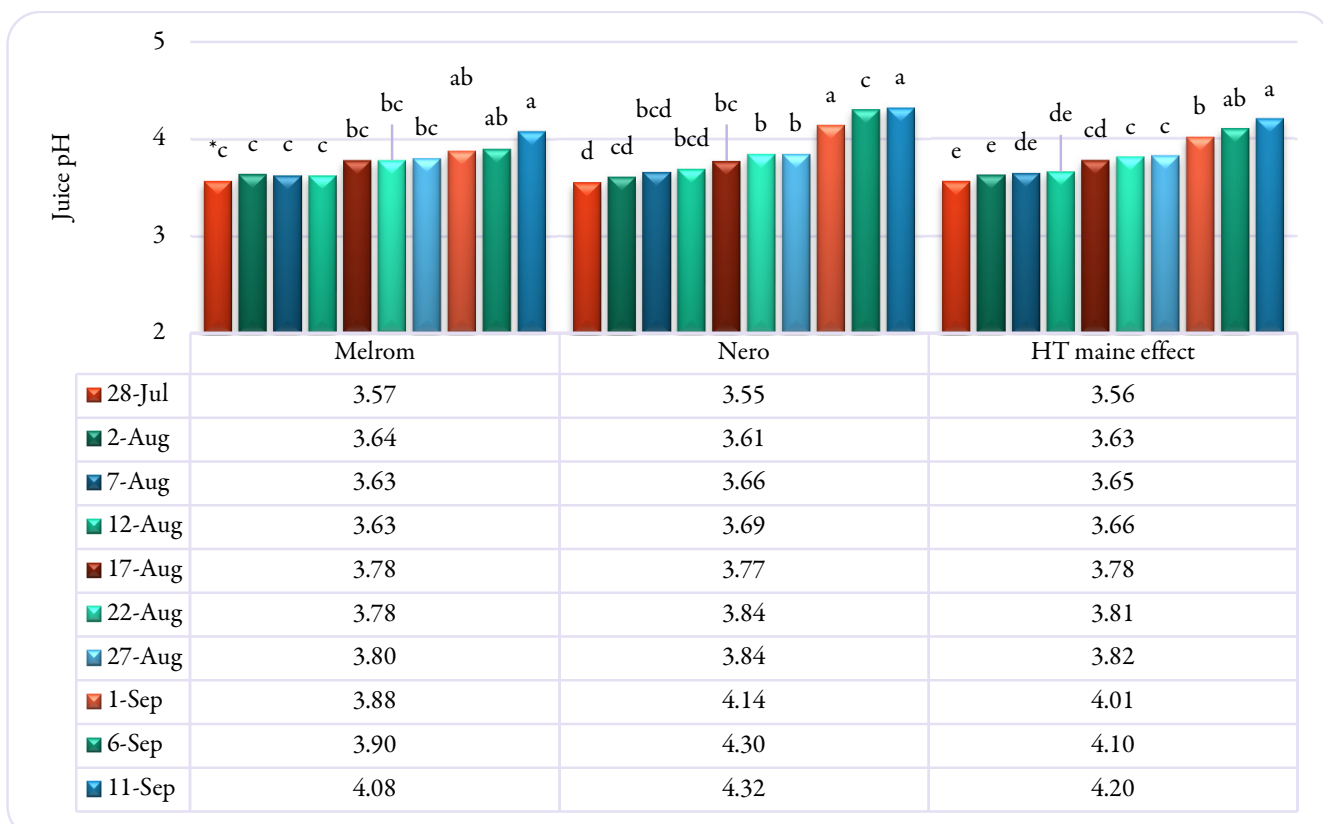

Figure 12. Harvest time effect depending on cultivar and HT main effect on juice $\mathrm{pH}$ on $A$. melanocarpa (Michx.) Elliot, 'Melrom' and 'Nero' cultivars (each value represents the average of three determination results)

${ }^{*}$ Different letters within the columns indicate statistically significant differences (Duncan's multiple range test, $\mathrm{p}<0.05$ )

Overall, berries with higher juice $\mathrm{pH}$ showed high dry weight $\left(\mathrm{r}=0.646^{* *}\right)$, total anthocyanins $(\mathrm{r}=$ $\left.0.478^{* *}\right)$ and, respectively, total soluble solids content $\left(\mathrm{r}=0.756^{* *}\right)$, but low vitamin $\mathrm{C}\left(\mathrm{r}=-0.478^{\circ \circ}\right)$ and total phenolics content $\left(\mathrm{r}=-0.610^{\circ}\right)$. Similar to Bolling et al. (2015) and Gralec et al. (2019) research papers, our study indicated a non - significant correlation between phenolics and anthocyanins $(r=-0.211)$. Consequently, in 2020, the optimum harvest time was related to the antagonistic variation between anthocyanins and both, vitamin $\mathrm{C}$ and phenolics, and was also influenced by the dehydration process evolution. Early harvesting, during the first decade of August, had the advantage of higher moisture and vitamin $\mathrm{C}$ and TPC levels above average, suitable for fresh fruit or juice consumption, with the consequence of under average anthocyanins levels. Contrarily, delaying the harvest after 27 August, although increased the TAC, resulted in low TPC, vitamin C, and moisture. In a similar experiment, the optimum harvest period reported by Engin and Mert (2020) in 2019 for 'Nero' and 'Viking' cultivars, studied in Turkey, in a drip-irrigated experimental plot, was the second week of September in terms of yield, the second and the third weeks in September, based on fruits antioxidant content, and the first and second weeks of October, for dry consumption.

\section{Conclusions}

The harvest season for Aronia melanocarpa cultivated in Arges County, Romania extended, in 2020, to 45 days (from 28 July to 11 September). Without an irrigation system, most of the fruits became visibly dehydrated after 11 September. 'Melrom' cultivar berries had significantly higher dry weight content, 251.43 $\pm 21.74 \mathrm{~g} \mathrm{~kg}^{-1}$ although 'Nero' showed a significantly higher vitamin $\mathrm{C}\left(1.87 \pm 0.25 \mathrm{~g} \mathrm{~kg}^{-1} \mathrm{DW}\right)$, total anthocyanins content $\left(29.71 \pm 5.36 \mathrm{gcy}^{3}\right.$ - glu kg $\left.{ }^{-1} \mathrm{DW}\right)$, juice $\mathrm{pH}(3.87 \pm 0.29)$, and a non significantly higher TPC ( $\left.67.66 \mathrm{~g} \mathrm{GAE} \mathrm{kg}^{-1}\right)$. Taken together the two cultivars, there was observed an increasing trend of dry weight content during the harvest season by $43.32 \%$ from 28 July to 11 September ( $40.81 \%$, for 'Melrom' and 
$45.78 \%$, for 'Nero'). Similar tendencies were followed by the anthocyanins content, with a gain of $54.15 \%$ ( $40.86 \%$, for 'Melrom' and $63.58 \%$, for 'Nero'), total soluble content, and juice $\mathrm{pH}$ whose values increased by $36.26 \%$ (21.68\%, for 'Melrom' and 52.13\%, for 'Nero') and 18.03\% (14.38\%, for 'Melrom' and 21.71\%, for 'Nero'), respectively, at the end of the harvest season. Vitamin $\mathrm{C}$ and total phenolics content underwent losses of $27.72 \%$ (23.68\%, for 'Melrom' and 28.92\%, for 'Nero' cultivar) and, respectively, $27.90 \%$ (27.24\%, for 'Melrom' and $28.51 \%$, for 'Nero'). The highest size effect was determined for harvest time regardless of the quality parameter. The most sensitive under experimental factors influence was TAC, followed by vitamin C.

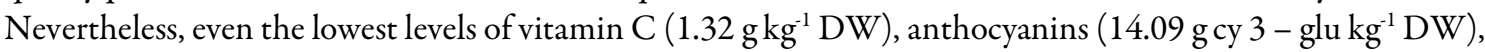
and phenolics (48.42 $\mathrm{g} \mathrm{GAE} \mathrm{kg}^{-1} \mathrm{DW}$ ) represent important antioxidant compounds content, counting Aronia 'Melrom' and 'Nero' cultivars as a functional food.

\section{Authors' Contributions}

Conceptualization: SC and IEM; Data curation: IEM, MP, MDD; Formal analysis: IEM, MP, MDD; Methodology: SC, IEM, MP, MDD; Writing - original draft: IEM, MP, MDD; Writing - review and editing: SC. Please add at the end: All authors read and approved the final manuscript.

\section{Acknowledgements}

This research received no specific grant from any funding agency in the public, commercial, or not-forprofit sectors.

\section{Conflict of Interests}

The authors declare that there are no conflicts of interest related to this article.

\section{References}

Bolling BW, Taheri R, Pei R, Kranz S, Yu M, Durocher SN, Brand MH (2015). Harvest date affects Aronia juice phenolics, sugars, and antioxidant activity, but not anthocyanin stability. Food Chemistry 187:189-196. https://doi.org/10.1016/j.foodchem.2015.04.106

Cosmulescu S, Trandafir I, Nour V (2017). Phenolic acids and flavonoids profiles of extracts from edible wild fruits and their antioxidant properties. International Journal of Food Properties 20(12):3124-3134. https://doi.org/10.1080/10942912.2016.1274906

Djuric M, Brkovic D, Milosevic D, Pavlovic M, Curcic S (2015). Chemical characterization of the fruit of black chokeberry grown on different types of soil. Revista de Chimie 66:178-781. https://doi.org/10.1.1.1059.5882\&rep=rep1\&type $=p d f$

Engin SP, Mert C (2020). The effects of harvesting time on the physicochemical components of Aronia berry. Turkish Journal of Agriculture and Forestry 44(4):361-370. https://doi.org/10.3906/tar-1903-130

Fuleki T, Francis FJ (1968). Quantitative methods for anthocyanins. 1. Extraction and determination of total anthocyanin in cranberries. Journal of Food Science 33(1):72-77. https://doi.org/10.1111/j.1365-2621.1968.tb00887.x

Gralec M, Wawer I, Zawada K (2019). Aronia melanocarpa berries: Phenolics composition and antioxidant properties changes during fruit development and ripening. Emirates Journal of Food and Agriculture 214-221. https://www.ejfa.me/index.php/journal/article/view/1921

Hornung TC, Biesalski HK (2019). Glut-1 explains the evolutionary advantage of the loss of endogenous vitamin Csynthesis. The electron transfer hypothesis. Evolution, Medicine, and Public Health 1(2019):221-231. https://doi.org/10.1093/emph/eoz024 
Jeppsson N, Johansson R (2000). Changes in fruit quality in black chokeberry (Aronia melanocarpa) during maturation. The Journal of Horticultural Science and Biotechnology 75(3):340-345. https://doi.org/10.1080/14620316.2000.11511247

Ochmian ID, GrajkowskiJ, Smolik M (2012). Comparison of some morphological features, quality, and chemical content of four cultivars of chokeberry fruits (Aronia melanocarpa). Notulae Botanicae Horti Agrobotanici ClujNapoca 40(1):253-260. https://doi.org/10.15835/nbha4017181

Oszmiański J, Wojdylo A (2005). Aronia melanocarpa phenolics and their antioxidant activity. European Food Research and Technology 221(6):809-813. https://doi.org/10.1007/s00217-005-0002-5

Remberg SF, Wold AB, Sønsteby A, Heide OM (2014). Effects of preharvest factors on berry quality. Acta Horticulturae 1017:181-187. https://doi.org/10.17660/ActaHortic.2014.1017.21

Sapožnikova EV, Dorofiejeva LS (1966). Opred'elenie koli estva askorbinovoj kisloty v okrašenych rast'ennych ekstraktach iodometri eskim metodom. Konsiervnaja i ovoš esušilnaja promyšlennost' 5:29-31.

Sim I, Suh DH, Singh D, Do SG, Moon KH, Lee JH, Lee CH (2017). Unraveling metabolic variation for blueberry and chokeberry cultivars harvested from different geo-climatic regions in Korea. Journal of Agricultural and Food Chemistry 65(41):9031-9040. https://doi.org/10.1021/acs.jafc.7b04065

Šnebergrová J, Čížková H, Neradova E, Kapci B, Rajchl A, Voldřich M (2014). Variability of characteristic components of aronia. Czech Journal of Food Sciences 32(1):25-30. https://doi.org/10.17221/540/2012-CJFS

Strik B, Finn C, Wrolstad R (2003). Performance of chokeberry (Aronia melanocarpa) in Oregon, USA. Acta Horticulturae 626:439-443. https://www.actahort.org/books/626/626_61.htm

Tolić MT, Krbavčić IP, Vujević P, Milinović B, Jurčević IL, Vahčić N (2017). Effects of weather conditions on phenolic content and antioxidant capacity in juice of chokeberries (Aronia melanocarpa L.). Polish Journal of Food and Nutrition Sciences 67(1):67-74. https://doi.org/10.1021/acs.jafc.7b04065

Wangensteen H, Bräunlich M, Nikolic V, Malterud KE, Slimestad R, Barsett H (2014). Anthocyanins, proanthocyanidins and total phenolics in four cultivars of Aronia: Antioxidant and enzyme inhibitory effects. Journal of Functional Foods 7:746-752. https://doi.org/10.3390/nu5030663

Won J, Shin H, Oh Y, Han H, Kwon Y, Kim D (2018). Tree growth and fruit characteristics of 'Nero' black chokeberry according to different cultivation regions and altitudes. Korean Journal of Plant Resources 31(2):136-148. https://doi.org/10.7732/kjpr.2018.31.2.136

Yang H, Kim YJ, Shin Y (2019). Influence of ripening stage and cultivar on physicochemical properties and antioxidant compositions of Aronia grown in South Korea. Foods 8(12):598 https://doi.org/10.3390/foods8120598
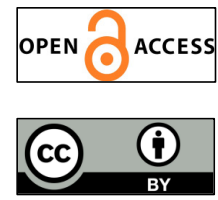

The journal offers free, immediate, and unrestricted access to peer-reviewed research and scholarly work. Users are allowed to read, download, copy, distribute, print, search, or link to the full texts of the articles, or use them for any other lawful purpose, without asking prior permission from the publisher or the author.

License - Articles published in Notulae Botanicae Horti Agrobotanici Cluj-Napoca are Open-Access, distributed under the terms and conditions of the Creative Commons Attribution (CC BY 4.0) License.

(C) Articles by the authors; UASVM, Cluj-Napoca, Romania. The journal allows the author(s) to hold the copyright/to retain publishing rights without restriction. 